\title{
Movement patterns of seaward migrating European eel (Anguilla anguilla) at a complex of riverine barriers: implications for conservation
}

\author{
A. T. Piper ${ }^{1}$, J. C. Svendsen ${ }^{2,3}$, R. M. Wright ${ }^{4} \&$ P. S. Kemp ${ }^{1}$ \\ ${ }^{1}$ International Centre for Ecohydraulics Research, School of Civil Engineering and the \\ Environment, University of Southampton, Highfield, Southampton SO17 1BJ, UK;, National \\ ${ }^{2}$ Institute of Aquatic Resources, Section for Freshwater Fisheries and Ecology Technical \\ University of Denmark, Vejlsøvej 39, DK-8600 Silkeborg, Denmark; \\ ${ }^{3}$ Interdisciplinary Centre of Marine and Environmental Research (CIIMAR), University of \\ Porto, Rua dos Bragas 289, 4050-123 Porto, Portugal; \\ ${ }^{4}$ Environment Agency, Rivers House, Threshelfords Business Park, Inworth Rd, Feering, \\ CO5 9SE, UK
}

\section{Correspondence: Adam T Piper (adam@prar.co.uk)}

Running headline: Downstream migration patterns in European eel

\begin{abstract}
River infrastructure such as weirs and hydropower stations commonly present migrating fish with multiple potential passage routes. Knowledge of the cues fish use to navigate such environments is required to protect migrants from hazardous areas and guide them towards safe passage, however, this is currently lacking for many species. Employing high-resolution positioning telemetry, this study examined movements of downstream migrating adult European eel, Anguilla anguilla, as they encountered a complex of water control structures in one location on the River Stour, southern England. The distribution of eels across five potential routes of passage differed from that predicted based on proportion of discharge alone. Certain routes were consistently avoided, even when the majority of flow passed through them. Passage distribution was partially explained by avoidance in the vicinity of a floating debris boom. Movement paths were non-randomly distributed across the forebay and eels moved predominantly within a zone 2-4 m from the channel walls. Understanding of avoidance and structure-orientation exhibited by eels will help advance effective guidance and downstream passage solutions for adults.
\end{abstract}

Keywords: fish passage; bypass; fishway; hydropower; migratory barriers. 
Many populations of diadromous fish are threatened by anthropogenic activities, such as overfishing and the construction of river infrastructure that impedes or blocks access to essential habitat (Limburg \& Waldman 2009; McCauley et al. 2015). The catadromous European eel (Anguilla anguilla, Linnaeus, 1758) exhibits a semelparous life history that includes an initial journey as larvae (leptocephali) across the Atlantic Ocean to the coasts of Europe and North Africa followed by an inland migration to estuaries, rivers and streams, where they may remain resident for between 2 and 20+ years. As adults, the eels will embark on an outward final $5000-6000 \mathrm{~km}$ migration to spawning grounds in the Sargasso Sea (Aarestrup et al. 2009; Bruijs \& Durif 2009). Compared to the 1980s, juvenile eel recruitment has reduced by 88 to $96 \%$ in many rivers (Dekker 2003; ICES 2014). As a result, the species is considered critically endangered (Jacoby \& Gollock 2014) and listed under Appendix II of the Convention on International Trade in Endangered Species of Wild Fauna and Flora (CITES). Accordingly, the European Union implemented the Eel Recovery Plan (2007) to establish management strategies to restore stocks (Council Regulation No. 1100/2007/EC), and the International Council for the Exploitation of the Sea recommended that mortality during the adult eel migration as a result of human induced stressors should be reduced to zero whenever possible (ICES 2014). include loss of habitat and reduced habitat quality (Feunteun 2002), bioaccumulation of toxins (Belpaire et al. 2009), impacts of parasites (Kirk 2003; Palstra et al. 2007) and disease (van Beurden et al. 2012; Van Ginneken et al. 2005), overharvest (Briand et al. 2003), and oceanic 
near the spawning grounds which may impair the survival and transport of leptocephali (Friedland et al. 2007; Kettle et al. 2008; Knights 2003). Loss of hydrological continuity due to the presence of river infrastructure, such as weirs and dams, limits both juvenile upstream migration and adult spawner escapement (Bruijs \& Durif 2009; Jansen et al. 2007; Verbiest et al. 2012; White \& Knights 1997). Estimates of the proportion of downstream migrating eels that reach the marine environment range between 15 and $96 \%$ in regulated rivers (Aarestrup et al. 2010; Breteler et al. 2007; Breukelaar et al. 2009; Feunteun et al. 2000; Verbiest et al. 2012; Winter et al. 2006).

River infrastructure may delay or prevent downstream migration (Acou et al. 2008; Behrmann-Godel \& Eckmann 2003), while hydropower and pumping stations cause direct mortality through blade strike, cavitation and pressure differences (Bruijs \& Durif 2009; Schilt 2007; Turnpenny et al. 1998). Mortality of adult eels at these facilities may range between 10 and 100\% (Calles et al. 2010; Carr \& Whoriskey 2008; Larinier 2008). Physical screens may be installed to prevent adult eels from entering intakes to pumps and turbines, but can be expensive and cause injury and mortality through collision and impingement (Calles et al. 2010; Hadderingh \& Jager 2002). Screens may also guide fish to alternative downstream passage routes. Guiding screens should create an attractive, or at least not an unattractive, environment (e.g. structural, hydrodynamic, acoustic) that does not induce avoidance and delay. Effective guidance for eel is considered lacking (Boubée 2014; Bruijs \& Durif 2009; Haro 2014), and for those designs tested so far, efficiencies are highly variable and generally lower than expected (Calles et al. 2012; Gosset et al. 2005; Marohn et al. 2014). Development of effective guidance requires improved understanding of fish response to environmental parameters associated with structures at realistic scales (Goodwin et al. 2006; Kemp et al. 2012). 
Downstream eel migration has previously been considered to be predominantly semi-

86

87 passive, with elements of both active swimming and drifting with the currents (Porcher 2002; Tesch 2003), and a tendency to follow bulk flow (Breteler et al. 2007; Bultel et al. 2014; Jansen et al. 2007). Similarly, downstream migration of juvenile salmonids was historically thought to reflect obligate passive displacement with flow (Flagg et al. 1983; Smith 1982 for Oncorhynchus sp.; Thorpe \& Morgan 1978; Tytler et al. 1978 for Salmo salar). This is now known not to be the case, as juvenile salmonids are capable of relatively strong swimming (e.g. Peake \& McKinley 1998), actively seek high velocity zones (Svendsen et al. 2007), and avoid rapid accelerations of flow (Enders et al. 2009; Kemp et al. 2005; Svendsen et al. 2011). Indeed, diadromous fish are likely to exhibit a complex repertoire of migratory behaviours to accommodate the diversity of physical and hydrodynamic cues they encounter as they move through freshwater and marine environments (Goodwin et al. 2014; Kemp et al. 2012; Smith et al. 2014).

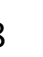

As predicted under assumptions of semi-passive downstream migration, the distribution of migratory adult eels at river bifurcations and flow diversion structures may be proportional to the flow passing each route (Breukelaar et al. 2009; Bruijs \& Durif 2009; Calles et al. 2013; Jansen et al. 2007; Piper et al. 2013). Recent studies cast doubt on the simplistic semi-passive drift assumption, however, and describe a wide variety of behaviours displayed by eels when approaching structures. These include active hesitation before passing trash racks (Bruijs \& Durif 2009), and altering of position in the water column and recurrent or searching behaviours on encountering rapid velocity gradients (Piper et al., 2015) and debris screens (Brown et al. 2009 for A. rostrata; Keeken et al. 2011 for A. anguilla). In flumes, eels associate closely with channel walls and structure (Adam et al. 1999; Russon et al. 2010) and may react to turbulent 
flow features (Russon et al. 2010; Silva et al. in press) and reject velocity acceleration (Newbold et al., 2015).

This study aimed to enhance understanding of the migratory behaviour of eels by exploring fine-scale movement and route choice of actively downstream moving adults in a field setting when presented with a variety of passage routes at one location. Using high resolution positioning acoustic telemetry, European eel were tracked through the forebay of a complex of water control structures, including both overshot and undershot sluices at a redundant hydropower site. Movement patterns were analysed and compared to those predicted based on the assumption of proportional passage with the flow through five available routes. Spatial distribution of eels across the forebay was examined to determine the influence of structural boundaries.

\section{MATERIALS AND METHODS}

\section{STUDY SITE}

The study was conducted on the River Stour, Southern England, in the forebay of a complex of water level control structures $\left(50^{\circ} 46^{\prime} 31.98^{\prime \prime} \mathrm{N}, 1^{\circ} 54^{\prime} 41.08^{\prime \prime W}\right)$ located $19 \mathrm{~km}$ upstream of the estuary. The complex comprises of two broad-crested Crump weirs $(15.2 \mathrm{~m}$ width, A; 14.8 m width, C, Fig. 1); a pool and weir fish pass (1.8 m width, B, Fig 1); an adjustable overshot radial weir (7.5 m width, D, Fig. 1); and a set of 6 undershot sluice gates on the downstream side of an intake channel (7.6 m width) that formerly led to two hydropower turbines that were removed in the 1970s (Redundant Hydropower - RHP, E, Fig. 1). At the intake, a vertical bar rack ( $7.6 \mathrm{~m}$ width, $55^{\circ}$ angle, $58 \mathrm{~mm}$ bar spacing), extends the 


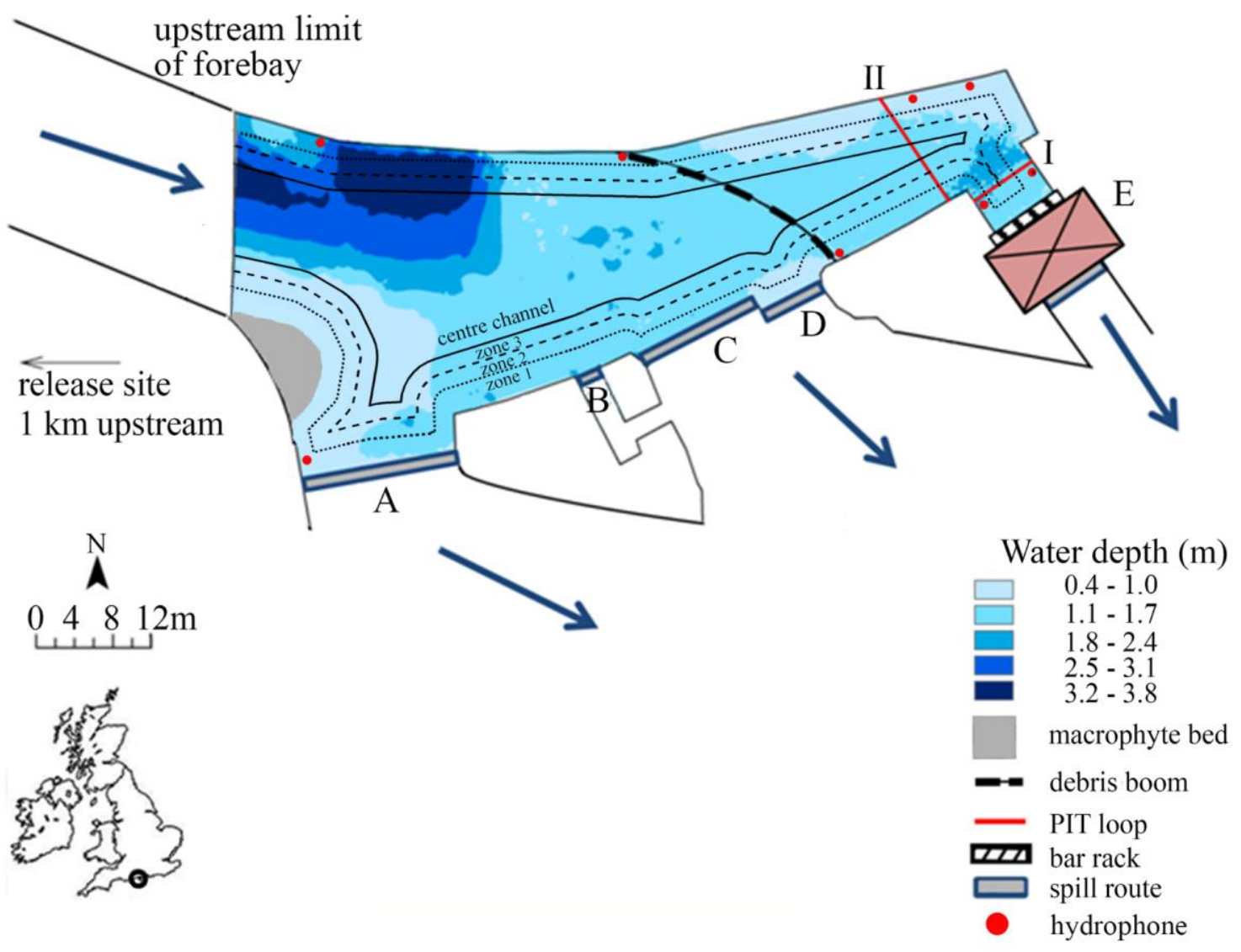

Fig. 1. Forebay bathymetry and location of structures (A and C - broadcrest weirs; B - pool and weir fish pass; D - radial weir, and E - an intake to a redundant hydropower (RHP) facility at Longham water works, River Stour, Dorset, UK. Red lines show PIT antennas I and II. Structures A to D are overshot discharge routes, whereas E (RHP intake) is undershot. Red dots denote the positions of hydrophones. For spatial analysis, the site was divided into four zones at increasing distances from the channel walls: Zone 1 (0 to $2 \mathrm{~m}$, small dashes); Zone 2 (2 to $4 \mathrm{~m}$, large dashes); Zone 3 (4 to 6 $\mathrm{m}$, solid line), and centre channel (the remainder of the site) 
Adjustable water control structures were maintained at fixed positions throughout the

study with RHP sluice gates $50 \%$ open. An automatic flood control gate upstream of the forebay diverted excess flow down an alternate channel and thereby regulated the total channel discharge passing the study site.

A downward focused raft-mounted Acoustic Doppler Current Profiler with onboard GPS (ADCP, Sontek M9 River Surveyor®; www.sontek.com) was used to map site bathymetry and quantify discharge flowing into the study site and through each water control structure (Fig. 1). For bathymetry, the ADCP measured distance to channel bed using a vertical acoustic beam (0.5 MHz), and was pulled from bank-to-bank along a zig-zag transect to sample the entire forebay (see Dinehart \& Burau 2005 for detailed description). For discharge, daily ADCP transect measurements in which the raft was pulled bank to bank perpendicular to flow were conducted across the inlet channel of the forebay, $4 \mathrm{~m}$ downstream of the debris boom, and 2 $\mathrm{m}$ upstream of structures A to D. Discharge was calculated within processing software RiverSurveyor Live v3.01 (Sontek; www.sontek.com) using established methods (Simpson 2001; SonTek 2010). Water level $(\mathrm{cm})$ and temperature $\left({ }^{\circ} \mathrm{C}\right)$ were recorded every 15 minutes throughout the study period by fixed loggers located near the debris boom $\left(\mathrm{HOBO}^{\circledR} \mathrm{U} 20\right.$, OnsetComp; www.onsetcomp.com). Temperature ranged from 7.9 to 8.6 (mean $8.1 \pm 1.3$ S.D.) over the study period. Flow patterns were generated through linear interpolation based on ADCP discrete transect measurements and continuously logged changes in water level.

\section{TELEMETRY CONFIGURATION AND VALIDATION}

Acoustic telemetry (Hydroacoustic Technology Inc.; www.htisonar.com) was employed to track 2-dimensional movements ( $\mathrm{x}$ and $\mathrm{y}$ ) of tagged eels within the study site. Eight hydrophones $(300 \mathrm{kHz})$ were positioned around the perimeter of the study area (Fig. 1) and 
detections were logged by a receiver (HTI, Model 290). As it was not possible to accurately determine the position of the fish in the shallow water column from acoustic detections alone, Passive Integrated Transponder (PIT) telemetry (Model LF-HDX-RFID, Oregon RFID; www.oregonrfid.com) was employed to indicate eel depth. A pass-over antenna was positioned across the full width of the intake channel (7.6 m length, $0.5 \mathrm{~m}$ width) (I, Fig 1), with a second antenna positioned across the channel $6.0 \mathrm{~m}$ upstream (14 $\mathrm{m}$ length, $0.5 \mathrm{~m}$ width) (II, Fig 1,).

The detection range of the acoustic tags was assessed at various positions throughout the study site. This enabled optimal positioning of the hydrophones and quantification of detection efficiency. Known tag locations demonstrated a minimum accuracy of $<1 \mathrm{~m}$ which is comparable to other studies (Brown et al. 2009; Svendsen et al. 2011). Similarly, PIT antenna range testing indicated consistent detection ( $>99 \%$ ) for depths $<0.2 \mathrm{~m}$ across both antennas. Both telemetry systems logged continually throughout the study period.

\section{FISH CAPTURE AND TAGGING PROCEDURE}

Actively migrating adult eels $(n=25)$ were trapped downstream of the RHP on five consecutive nights in November 2009, within the typical migration period for this river (Roger Castle, pers. comm.). Fish were transferred to in-river perforated holding barrels and held for a maximum of $8 \mathrm{~h}$ before being individually anesthetised (Benzocaine $0.2 \mathrm{~g} \mathrm{l}^{-1}$ ). Morphometric measurements were collected: wet mass $(M, \mathrm{~g})$; total length $\left.\left(L_{T}\right), \mathrm{mm}\right)$; left pectoral fin length from insertion to the tip (mm), and maximum vertical and horizontal left eye diameter $(\mathrm{mm})$. All individuals captured exceeded $450 \mathrm{~mm}\left(L_{T}\right)$ and were therefore presumed to be female (Durif et al. 2005). Degree of sexual maturation was quantified prior to tagging using two metrics; the Ocular index ( $\left.I_{O}\right)$, according to Pankhurst (1982), and Fin Index $\left(I_{F}\right)$, according to Durif et al. (2009). European eel with $I_{O} \geq 6.5$, and $I_{F} \geq 4.3$ (females only) were considered to 
be at the migratory silver stage. The first five eels fulfilling these criteria were selected for tagging each night. Tagged eels ranged from 635 to $827 \mathrm{~mm} L_{T}, 596-1049 \mathrm{~g} M$, with median $I_{O} 8.9$ (range $6.8-12.3$ ) and median $I_{F} 4.6$ (range 4.4 to 5.0 ).

An acoustic tag (HTI model 795G, 11mm diameter, 25mm length, $4.5 \mathrm{~g}$ mass in air, 300kHs, $0.7-1.3 \mathrm{~s}$ transmission interval), and Passive Integrated Transponder (PIT) tag (HDX, $3.65 \mathrm{~mm}$ diameter, $32 \mathrm{~mm}$ length, $0.8 \mathrm{~g}$ mass in air, Texas Instruments; www.ti.com) were surgically implanted into the peritoneal cavity of each eel following methods similar to Baras and Jeandrain (1998) under UK Home Office licence. No individual surgical procedure exceeded 3 minutes.

After tagging, eels were transported to the release location $(1 \mathrm{~km}$ upstream of the study site) and held for 10-12 hours in a barrel to allow post-operative recovery and acclimation before release. No mortality was observed. To reduce bias in route choice, the holding barrel was tethered in the centre of the channel following previous studies (Piper et al. 2013; Svendsen et al. 2010). On each study night in darkness (20:00 h), the barrel lid was removed remotely with rope and pulley to minimise disturbance and allow individuals to leave volitionally.

\section{DATA ANALYSIS}

Acoustic tag detections were manually marked to remove background noise, then processed and corrected for speed of sound using MarkTag v5 and AcousticTag v5 software (Hydroacoustic Technology Inc., www.htisonar.com). Only detections within the perimeter of the hydrophone array were used (Ehrenberg \& Steig 2003; Svendsen et al. 2011). Timestamped Universal Transverse Mercator (UTM) designated detections (eel tracks) were 
imported into ArcMap v10 (ESRI; www.esri.com). Fish were deemed to have entered the study domain when tracks crossed a hypothetical cross-channel line between the two most upstream hydrophones at the upstream entrance to the forebay (Fig. 1). Passage was deemed to have occurred at the last detection point before an individual passed downstream of one of the five structures (A to E, Fig. 1). Residence time was calculated as the duration between first and last detection in the study domain before downstream passage. PIT records were examined for detections at the times when acoustic tracks intersected antenna locations. Positive detection provided a surrogate measure of near-bed $(\leq 20 \mathrm{~cm})$ movement.

Randomization tests of goodness of fit (200 replicates) (McDonald 2009) were used to assess whether: 1) the number of fish that passed varied between nights, and 2) passage through the five available routes was proportional to flow. Where assumptions of normality and homogeneity of variance were met. one-way ANOVAs were used to test for differences in the body length, ocular index and fin index of eels that passed the five available downstream routes. Buffer analysis was conducted on mapped tracks in ArcMap to explore spatial patterns of eel movement across the forebay. Three edge zones (buffers) of $2 \mathrm{~m}$ width (to encompass the maximum possible error in fish positioning i.e. $\pm 1 \mathrm{~m}$ ) were imposed inside the structural site perimeter (zone 1: $0-2$, zone 2: $2-4$, and zone 3: $4-6 \mathrm{~m}$ from channel walls) and a fourth zone (centre channel) encompassed the remainder of the site (Fig. 1.). For each eel, the length of track falling within each of the four zones was calculated and weighted to account for the difference in area covered by each zone $(20.9,18.9,17.2$ and $43.0 \%$ of total site area, respectively). Weighted lengths were compared between zones using a one-way repeated measures ANOVA with pairwise comparisons and Tukeys post-hoc test. The GreenhouseGeisser correction was applied where data violated the assumption of sphericity. Values are 
quoted as mean \pm S.E. The significance level was 0.05 . Statistical analyses were carried out using IBM SPSS v21 (IBM; www-01.ibm.com/software/uk/analytics/spss).

\section{RESULTS}

251

Of the 25 fish released, 19 passed downstream via the five available routes (Fig. 2). Three individuals remained undetected, and a further three were detected briefly in the forebay entrance, but returned upstream and were thus excluded from further analysis. The number of fish that passed did not vary between nights (randomisation test, $\mathrm{p}=0.82$ ). Fish took between min (Fig. 3). Passage always occurred during the hours of darkness.

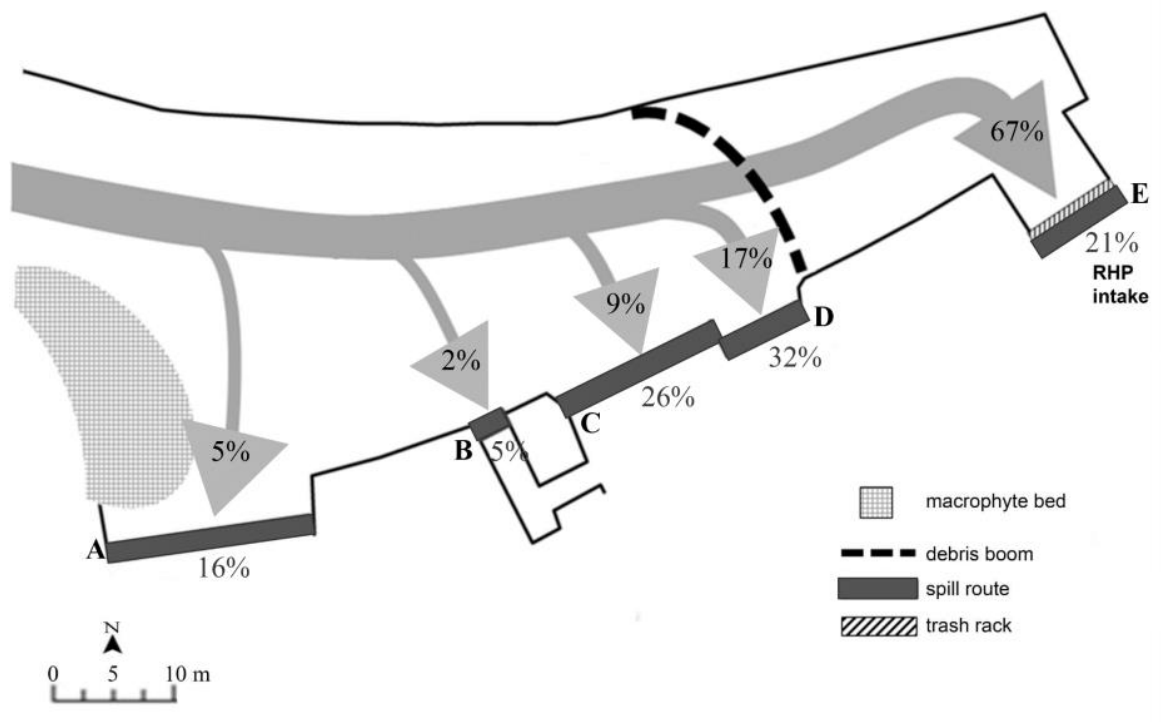

Fig. 2. Passage routes of downstream migrating adult eel (Anguilla anguilla) $(n=19)(\%)$ via two broad crested weirs $(A, C)$, a pool and weir fish pass (B), a drop weir (D) and a redundant hydropower (RHP) intake (E) at Longham Water Works, river Stour, UK. Arrows indicate water discharge routes, with percentages (in arrow heads) indicating total mean channel flow through each route. The proportion of eels that passed the routes differed $(p<0.01)$ from that predicted based on the distribution of flow through the routes. 


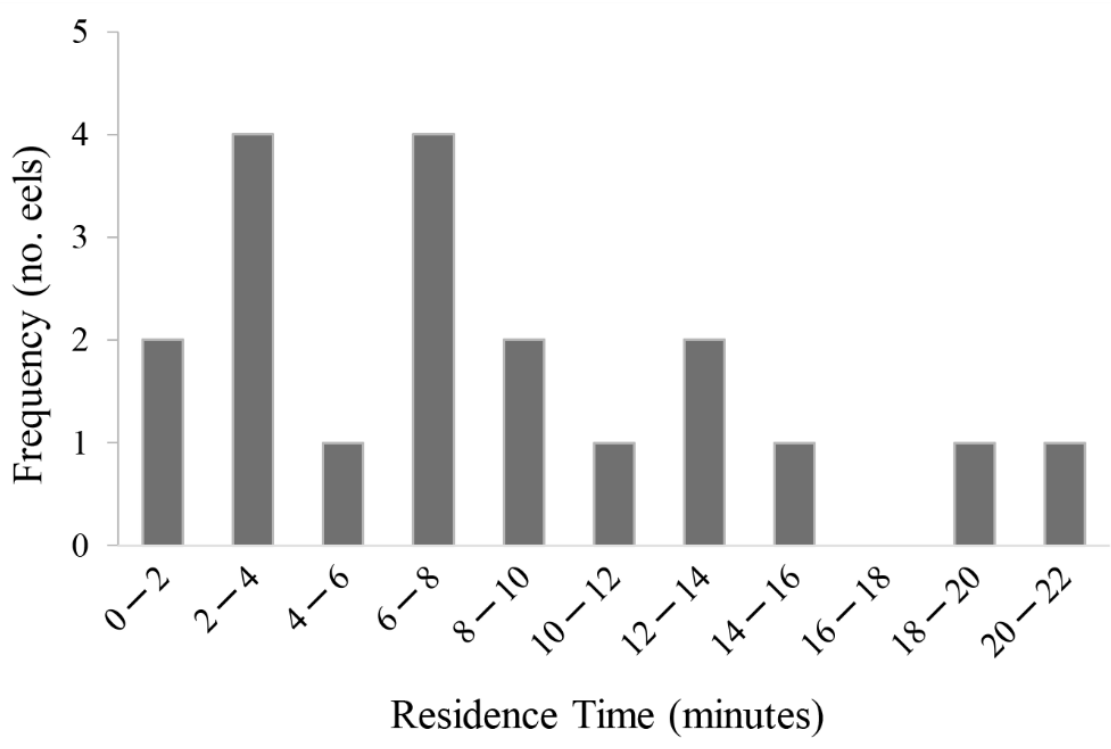

Fig. 3. Residence time of downstream migrating adult eel (Anguilla anguilla) $(n=19)$ within the forebay of a complex of water control structures at Longham, UK, prior to passage downstream via one of five flow spill routes.

Mean total flow into the forebay was $12.88 \pm 0.2 \mathrm{~m}^{3} \mathrm{~s}^{-1}$. The proportion of flow spilling via each passage route remained reasonably consistent throughout the study period, irrespective of minor fluctuations in total discharge entering the study site. Eels passed the structures in proportions that differed from the division of flow through the five routes (randomisation test, $\mathrm{p}=0.01)$. The majority of individuals $(63 \%)(\mathrm{n}=12)$ initially swam downstream with a relatively direct path towards the debris boom, although most ( 8 individuals) trajectories diverted on encountering it. Although $67 \%$ of river flow passed through the RHP intake, only $21 \%$ of fish descended via this route (Fig. 2). There was no relationship between eel body length, ocular index and fin index and the passage route used by downstream migrants $\left(\mathrm{F}_{4,14}=\right.$ $0.356, p=0.836 ; F_{4,14}=0.316, p=0.862 ; F_{4,14}=0.292, p=0.878$, respectively). Sixteen percent of individuals showed comparatively direct paths to the point of passage. The remaining eels either explored, making lateral movements transverse to the direction of 
286 flow with a non-direct path, or initially rejected a structure, i.e. abrupt switch from downstream 287 to upstream swimming ( $>90^{\circ}$ turn angle) before subsequently passage. The highest depth

288

289

290

291

292

293

294

295

296

297

298

299

300

Rejection behaviour was exhibited by five individuals in the vicinity of the debris boom. Eels rejected either at a point directly upstream $(<2.5 \mathrm{~m})$ of the boom (Fig. 4a), or shortly after passing underneath it (Fig. 4b). Several individuals showed less abrupt changes in direction and followed along the upstream edge of the boom (Fig. 4c). Only four individuals passed downstream of the boom, of which three exhibited an initial rejection between 0.9 and $2.8 \mathrm{~m}$ upstream of RHP bar rack, although all ultimately passed through the intake. Four eels recaptured at a trap downstream were alive and had no sign of external damage. 
a)

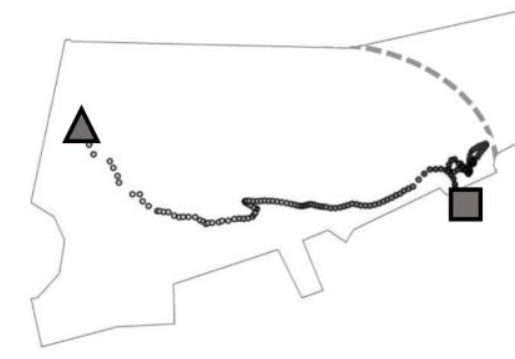

b)

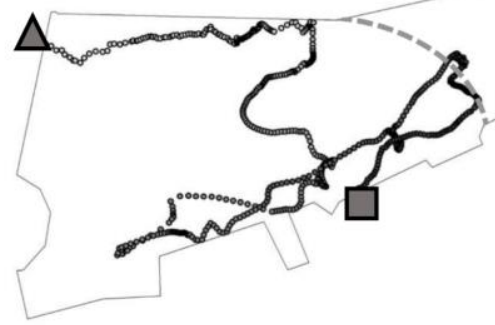

c)
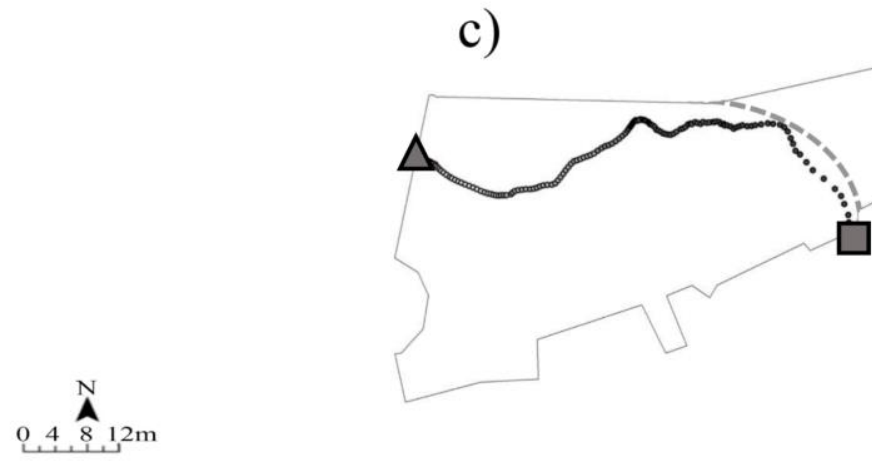

Fig. 4. Examples of tracks of three downstream migrating adult eels (Anguilla anguilla) that a) rejected immediately upstream of a debris boom (dashed line), b) rejected immediately downstream of the boom, and c) changed direction at the boom and swam parallel to it before passing the radial weir. Grey triangle and square denote the start and end of tracks, respectively. the site $\left(\mathrm{F}_{1.53,27.47}=10.02, \mathrm{p}<0.01\right)$. Instead, eels predominantly moved within a zone extending 2 to $4 \mathrm{~m}$ inside of the channel walls (Fig. 5). Less than $19 \%$ of total track lengths (unweighted) were potentially in contact with structures $(<2 \mathrm{~m})$. 


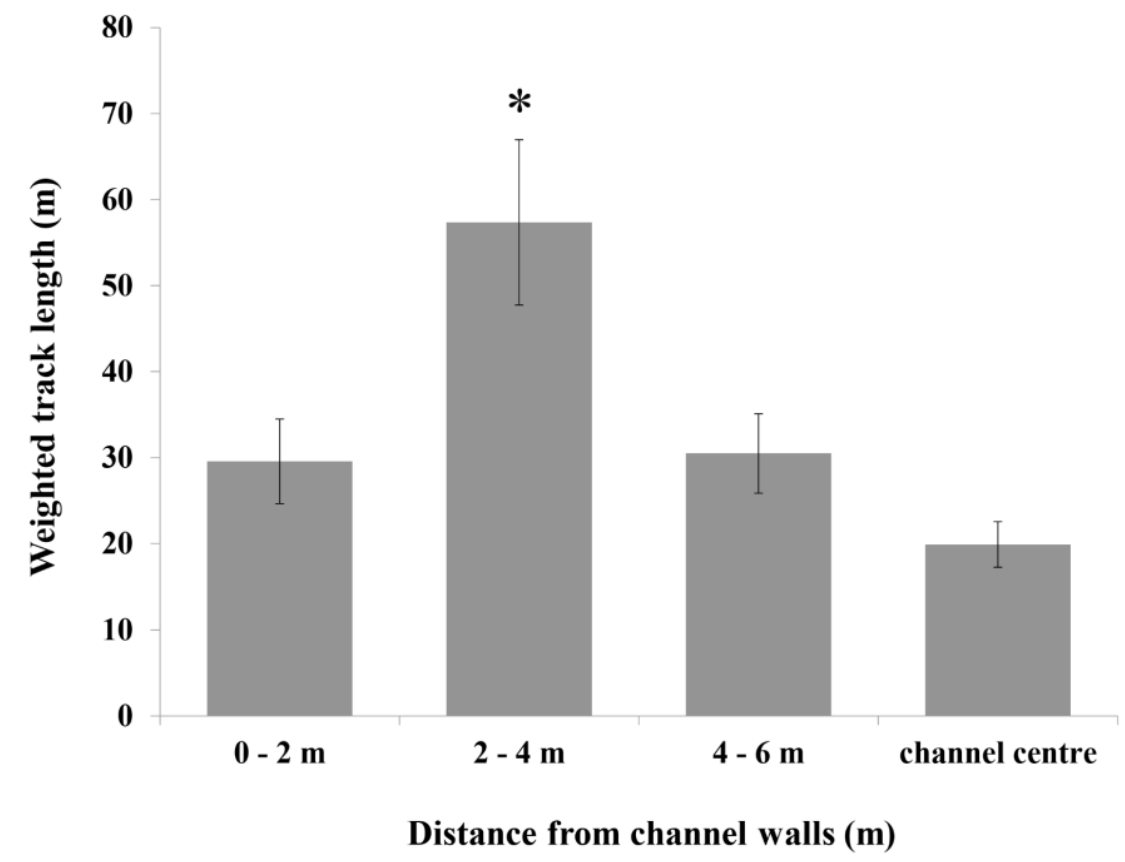

311

Fig. 5. Mean weighted track length of tagged eels (Anguilla anguilla) within $\mathbf{2} \mathbf{m}$ wide zones extending between 0 and $6 \mathrm{~m}$ inside the site boundary, and a fourth zone which encompassed the channel centre (grey bars) \pm 1 standard error. * denotes significant difference from all other groups $(p<0.05)$.

Eel swim depth determined by PIT telemetry on the approach to, and within, the RHP intake channel was within $0.2 \mathrm{~m}$ of the channel bed for all individuals that descended via this route $(n=4)$. Water depth in the vicinity of the antennas ranged from 0.4 to $1.7 \mathrm{~m}$, indicating that eel movements were within the lower $12-50 \%$ of the water column.

DISCUSSION

Facilitating effective protection, guidance and passage of seaward migrating adult eel at river infrastructure is an important component of their conservation and management (Feunteun 2002; Han et al. 2008; Haro et al. 2000; Jellyman et al. 2002). The distribution of European eel passing five water control structures did not coincide with the predominant flow 
direction, demonstrating that individuals were not passively transported downstream with the current. The principal spill route (RHP) passed only $21 \%$ of eels, with many showing avoidance behaviour at a cross-channel debris boom upstream. Further, swim paths were not evenly distributed across the study site; eels predominantly moved within a zone $2-4 \mathrm{~m}$ from the channel walls. The highly variable movement patterns revealed by fine-scale telemetry demonstrated a strong behavioural component to eel descent at riverine structures.

Eel movements in the forebay upstream of the debris boom initially coincided with the route of bulk flow, as predicted (Breukelaar et al. 2009; Bruijs \& Durif 2009; Calles et al. 2013; Jansen et al. 2007; Piper et al. 2013); however, final downstream passage routes did not reflect this pattern. Studies that report proportion of discharge as the main determinant of eel route selection were typically conducted in large, relatively uniform approach channels with limited variation in passage route (Gosset et al. 2005; Jansen et al. 2007; Travade et al. 2010). In the current study site, which encompassed multiple passage routes including undershot and overshot spill structures in close proximity, movement patterns were highly variable. The debris boom influenced eel distribution across passage routes, apparently modifying behaviour in the upstream vicinity with clear rejection observed in five individuals and less abrupt changes in direction in three others. Mark and recapture studies conducted at the same location by the Environment Agency in 2010 and 2011 in which a sample of downstream migrating adult eels were floy tagged and released upstream of the study site $(n=87 \& 194$, ranging from 356 to $815 \& 480$ to $790 \mathrm{~mm}$ in 2010 and 2011, respectively) indicated a recapture rate of 29 and $17 \%$ of tagged individuals in the RHP trap in 2010 and 2011, respectively. This is broadly comparable with the $21 \%$ which descended via this route in the current acoustic telemetry study suggesting that the observed migration patterns are typical 
for this site. The debris boom effectively diverted eels towards the two structures immediately upstream (C and D) which spilled only $26 \%$ of flow, but passed $58 \%$ of fish.

The boom projected $40 \mathrm{~cm}$ down from the water surface (total water depth: 1 to 1.6 $\mathrm{m}$ ), while the eels tended to be benthic-oriented, in common with previous studies (Brown et al. 2009; Gosset et al. 2005). Rejection at the debris boom was, therefore, unlikely to be a consequence of physical contact with the structure. It was not possible to decouple the physical influence of the debris boom from other environmental factors within this area. Eels have been shown to react to hydrodynamic features independent of physical contact with structures. In a recent flume study, $46 \%$ of eels switched from downstream to upstream swimming as they encountered an accelerating velocity gradient created by a flow constriction (Newbold et al. 2015). In a manipulated flow experiment at the RHP intake, Piper et al. (2015) observed that downstream migrating tagged eel predominantly rejected rapid water velocity gradients created by flow constriction, yet showed slower, exploratory movements on encountering low gradients. The boom likely induced a downstream sweeping flow parallel to the upstream face (Odeh \& Orvis 1998) and flow distortion with turbulent upwelling in the area immediately downstream (Toniolo 2014). Such hydrodynamic conditions may have deterred some eels, causing them to return upstream, and guided others towards structures $\mathrm{C}$ and $\mathrm{D}$.

Surface guidance devices such as floating booms, louvers and guide walls have been used with some success for diverting downstream migrating juvenile salmonids (smolts) towards safe passage routes (Adams et al. 2001; Hanson 1999; Odeh \& Orvis 1998; Scruton et al. 2008). For example, a floating louver installed at a hydroelectric facility on the Exploits 
River, Canada, achieved a fish guidance efficacy of 54 to $73.3 \%$ (Scruton et al. 2003) and an

377

378 angled surface wall at Bellows Falls power station, Connecticut River, US, guided $84 \%$ of smolts to a sluice gate (Odeh \& Orvis 1998). In contrast to eels, smolts typically travel higher in the water column when migrating downstream (Ruggles 1980). Nevertheless, observed rejection by eels at the debris boom suggests that surface structures may also have application for eel guidance in shallow water sites.

Eels predominantly followed paths that aligned with the structural perimeter of the study site, maintaining a distance of on average 2-4 $\mathrm{m}$ from the channel walls or water control structures. It is unclear how eels navigated along this route without making contact with the channel wall. There was little reduction of water depth near the vertical engineered perimeter walls with no distinctive topographic feature (e.g. trench or ridge) that would explain the bias in the distribution. Although the dark and highly turbid conditions in the forebay likely limited the visual field, it is recognised that eels, like other fish, derive navigational cues from flow field distortion created by fixed structures, detected through the mechanosensory system (Kalmijn 1989; Montgomery et al. 2000; Montgomery et al. 1995; Nestler et al. 2000).

Fine scale observations in the current study revealed that downstream migrating eels do not necessarily 'go with the flow'. Avoidance and structure-oriented behaviours provide optimism for the development of eel passage solutions in situations where demands for hydroelectric generation and water abstraction dictate that only a relatively small amount of flow is available to pass down alternate routes (e.g. bypasses). Effective guidance measures to divert eels away from the bulk flow passing deleterious routes (e.g. turbines and pumps) and towards safe passage is urgently needed to aid their conservation. As the mechanisms 
400 that underpin the behaviours observed in this study remain unclear, further investigation is 401 needed to examine the fine scale response of eel to specific and well defined cues (Anderson, 402 1988; Schilt, 2007; Williams et al., 2012), especially to relatively simple structures like 403 surface booms in shallow water. Given the results presented and other recent advances (e.g. 404 Newbold et al., 2015, Piper et al., 2015, Russon et al., 2010), further investigation of eel 405 reponse to hydrodynamic features synonymous with water control structures is likely to prove 406 valuable in the development of guidance devices.

407

\section{ACKNOWLEDGEMENTS}

409 This study was joint-funded by the University of Southampton and the Environment Agency, 410 UK. This research was supported by a grant (SFRH/BPD/89473/2012) from the Foundation 411 for Science and Technology (FCT) in Portugal to JCS. The authors would like to thank 412 Sembcorp Bournemouth Water for making the study facilities available and staff assistance 413 during set-up. Thanks are also due to Paula Rosewarne Alan Piper, Roger Castle and Jim 414 Davis for assistance in the field. 
Aarestrup, K., Okland, F., Hansen, M.M., Righton, D., Gargan, P., Castonguay, M.,

Bernatchez, L., Howey, P., Sparholt, H., Pedersen, M.I. \& McKinley, R.S. 2009. Oceanic

Spawning Migration of the European Eel (Anguilla anguilla). Science 325: 1660.

Aarestrup, K., Thorstad, E.B., Koed, A., Svendsen, J.C., Jepsen, N., Pedersen, M.I. \&

Økland, F. 2010. Survival and progression rates of large European silver eel Anguilla anguilla in late freshwater and early marine phases. Aquatic Biology 9: 263-270.

Acou, A., Laffaille, P., Legault, A. \& Feunteun, E. 2008. Migration pattern of silver eel (Anguilla anguilla, L.) in an obstructed river system. Ecology of Freshwater Fish 17: 432442.

Adam, B., Schwevers, U. \& Dumont, U. 1999. Planungshulfen fur den Bau funktionfahiger Fischaufstiegsanlagen. Bibliothek Natur and Wissenschaft Band 16: 1-63.

Adams, N., Johnson, G.E., Rondorf, D.W., Anglea, S.M. \& Wik, T.O. 2001. Biological evaluation of the behavioral guidance structure at Lower Granite Dam on the Snake River, Washington in 1998. Pacific Northwest National Lab., Richland, WA (US).

Anderson, J. J. 1988. Diverting migrating fish past turbines. Northwest Environmental Journal 4: 109-128.

Baras, E. \& Jeandrain, D. 1998. Evaluation of surgery procedures for tagging eel Anguilla anguilla with biotelemetry transmitters. Hydrobiologia 371-372: 107-111.

Behrmann-Godel, J. \& Eckmann, R. 2003. A preliminary telemetry study of the migration of silver European eel (Anguilla anguilla L.) in the River Mosel, Germany. Ecology of Freshwater Fish 12: 196-202.

Belpaire, C., Goemans, G., Geeraerts, C., Quataert, P., Parmentier, K., Hagel, P. \& De Boer, 
Boubée, J. Year. Upstream and Downstream Passage of Eels in New Zealand, 20 Years on-

Breteler, J.K., Vriese, T., Borcherding, J., Breukelaar, A., Jorgensen, L., Staas, S., de Laak,

G. \& Ingendahl, D. 2007. Assessment of population size and migration routes of silver eel in the river Rhine based on a 2-year combined mark-recapture and telemetry study. Ices Journal of Marine Science 64: 1450-1456.

Breukelaar, A.W., Ingendahl, D., Vriese, F.T., de Laak, G., Staas, S. \& Breteler, J.G.P.K. 2009. Route choices, migration speeds and daily migration activity of European silver eels Anguilla anguilla in the River Rhine, north-west Europe. Journal of Fish Biology 74: 21392157.

Briand, C., Fatin, D., Fontenelle, G. \& Feunteun, E. 2003. Estuarine and fluvial recruitment of the European glass eel, Anguilla anguilla, in an exploited Atlantic estuary. Fisheries Management and Ecology 10: 377-384.

Brown, L.S., Haro, A. \& Castro-Santos, T. 2009. Three-dimensional movements and behaviors of silver-phase migrant American eels at a small hydroelectric facility. American Fisheries Society Annual Meeting 58. Bethesda, Maryland.

Bruijs, M. \& Durif, C. 2009. Silver Eel Migration and Behaviour. In: Thillart, G., Dufour, S. \& Rankin, J.C., eds. Spawning Migration of the European Eel. Fish \& Fisheries Springer, pp. $65-95$.

462 Bultel, E., Lasne, E., Acou, A., Guillaudeau, J., Bertier, C., \& Feunteun, E. 2014. Migration behaviour of silver eels (Anguilla anguilla) in a large estuary of Western Europe inferred from acoustic telemetry. Estuarine, Coastal and Shelf Science 137: 23-31. 
465 Calles, O., Karlsson, S., Hebrand, M. \& Comoglio, C. 2012. Evaluating technical improvements for downstream migrating diadromous fish at a hydroelectric plant. Ecological Engineering 48: 30-37.

Calles, O., Karlsson, S., Vezza, P., Comoglio, C. \& Tielman, J. 2013. Success of a lowsloping rack for improving downstream passage of silver eels at a hydroelectric plant. Freshwater Biology 58: 2168-2179.

Calles, O., Olsson, I.C., Comoglio, C., Kemp, P.S., Blunden, L., Schmitz, M. \& Greenberg, L.A. 2010. Size-dependent mortality of migratory silver eels at a hydropower plant, and implications for escapement to the sea. Freshwater Biology 55: 2167-2180.

Carr, J.W. \& Whoriskey, F.G. 2008. Migration of silver American eels past a hydroelectric dam and through a coastal zone. Fisheries Management and Ecology 15: 393-400. Dekker, W. 2003. Status of the European eel stock and fisheries. In: Aida, K., Tsukamoto, K. \& Yamauchi, K., eds. Eel Biology. Springer, pp. 237-254.

Dinehart, R. \& Burau, J. 2005. Repeated surveys by acoustic Doppler current profiler for flow and sediment dynamics in a tidal river. Journal of Hydrology 314: 1-21.

Durif, C., Dufour, S. \& Elie, P. 2005. The silvering process of Anguilla anguilla: a new classification from the yellow resident to the silver migrating stage. Journal of Fish Biology 66: 1025-1043.

Durif, C.M., Ginneken, V., Dufour, S., Müller, T. \& Elie, P. 2009. Seasonal Evolution and Individual Differences in Silvering Eels from Different Locations. In: van den Thillart, G., Ehrenberg, J.E. \& Steig, T.W. 2003. Improved techniques for studying the temporal and spatial behavior of fish in a fixed location. Ices Journal of Marine Science 60: 700-706. Enders, E.C., Gessel, M.H. \& Williams, J.G. 2009. Development of successful fish passage structures for downstream migrants requires knowledge of their behavioural response to accelerating flow. Canadian Journal of Fisheries and Aquatic Sciences 66: 2109-2117. 
490

491

492

493

494

495

496

497

498

499

500

501

502

503

504

505

506

507

508

509

510

511

512

Feunteun, E., Acou, A., Laffaille, P., \& Legault, A. 2000. European eel (Anguilla anguilla):

Prediction of spawner escapement from continental population parameters. Canadian Journal of Fisheries and Aquatic Sciences 57: 1627-1635.

Feunteun, E. 2002. Management and restoration of European eel population (Anguilla anguilla): An impossible bargain. Ecological Engineering 18: 575-591.

Flagg, T.A., Prentice, E.F. \& Smith, L.S. 1983. Swimming stamina and survival following direct seawater entry during parr-smolt transformation of coho salmon (Oncorhynchus kisutch). Aquaculture 32: 383-396.

Friedland, K.D., Miller, M.J. \& Knights, B. 2007. Oceanic changes in the Sargasso Sea and declines in recruitment of the European eel. ICES Journal of Marine Science: Journal du Conseil 64: 519-530.

Goodwin, R.A., Nestler, J.M., Anderson, J.J., Weber, L.J. \& Loucks, D.P. 2006. Forecasting 3-D fish movement behavior using a Eulerian-Lagrangian-agent method (ELAM). Ecological Modelling 192: 197-223.

Goodwin, R.A., Politano, M., Garvin, J.W., Nestler, J.M., Hay, D., Anderson, J.J., Weber, L.J., Dimperio, E., Smith, D.L. \& Timko, M. 2014. Fish navigation of large dams emerges from their modulation of flow field experience. Proceedings of the National Academy of Sciences 111: 5277-5282.

Gosset, C., F. Travade, C. Durif, J. Rives, P. Elie,. 2005. Tests of two types of bypass for downstream migration of eels at a small hydroelectric power plant. River research and applications 21: 1095-1105.

Hadderingh, R. \& Jager, Z. 2002. Comparison of fish impingement by a thermal power station with fish populations in the Ems Estuary. Journal of Fish Biology 61: 105-124. 

analysis of population genetic composition in the overexploited Japanese eel Anguilla japonica. Marine Biology 155: 613-621.

Hanson, B.N. 1999. Effectiveness of two different surface bypass facilities on the Connecticut River to pass emigrating Atlantic salmon (Salmo salar) juvenile salmonids. Proceedings of the Innovations in Fish Passage Technology: 43-60.

Haro, A. 2014. Downstream Passage and Movements of Silver-Phase American Eels at Three Hydroelectric Projects on the Shetucket River, Connecticut. Proceedings of the 144th Annual Meeting of the American Fisheries Society. Aug 17 - 21 2014, Québec City

Haro, A., Richkus, W., Whalen, K., Hoar, A., Busch, W., Lary, S., Brush, T. \& Dixon, D. 2000. Population decline of the American eel: implications for research and management. Fisheries 25: 7-16.

ICES. 2014. Report of the Joint EIFAAC/ICES/GFCM Working Group on Eel. 3-7 November 2014, Rome, Italy. Jacoby, D. \& Gollock, M. 2014. Anguilla anguilla. The IUCN Red List of Threatened Species. Version 2014.2. . Jansen, H.M., Winter, H.V., Bruijs, M.C.M. \& Polman, H.J.G. 2007. Just go with the flow? Route selection and mortality during downstream migration of silver eels in relation to river discharge. Ices Journal of Marine Science 64: 1437-1443. Jellyman, D., Chisnall, B., Sykes, J. \& Bonnett, M. 2002. Variability in spatial and temporal abundance of glass eels (Anguilla spp.) in New Zealand waterways. New Zealand Journal of Marine and Freshwater Research 36: 511-517. 
538 Keeken, O.A.v., Viscount, D. \& Winter, H.V. 2011. Behaviour of eels around a fish

539 exclusion system with strobe lights at pumping station Ijmuiden. DIDSON measurements.

540 Wageningen: Institiute for Marine Resources and Ecosystem Studies (IMARES).

541 Kemp, P.S., Anderson, J.J. \& Vowles, A.S. 2012. Quantifying behaviour of migratory fish:

542 Application of signal detection theory to fisheries engineering. Ecological Engineering 41:

$543 \quad 22-31$.

544 Kemp, P.S., Gessel, M.H. \& Williams, J.G. 2005. Fine-scale behavioral responses of Pacific

545 salmonid smolts as they encounter divergence and acceleration of flow. Transactions of the 546 American Fisheries Society 134: 390-398.

547 Kettle, A.J., Bakker, D.C.E. \& Haines, K. 2008. Impact of the North Atlantic Oscillation on 548 the trans-Atlantic migrations of the European eel (Anguilla anguilla). Journal of Geophysical 549 Research 113: G03004.

550 Kirk, R.S. 2003. The impact of Anguillicola crassus on European eels. Fisheries

$551 \quad$ Management and Ecology 10: 385-394.

552 Knights, B. 2003. A review of the possible impacts of long-term oceanic and climate changes 553 and fishing mortality on recruitment of anguillid eels of the Northern Hemisphere. Science of 554 the Total Environment 310: 237-244.

555 Larinier, M. 2008. Fish passage experience at small-scale hydro-electric power plants in 556 France. Hydrobiologia 609: 97-108.

557 Limburg, K.E. \& Waldman, J.R. 2009. Dramatic declines in North Atlantic diadromous 558 fishes. Bioscience 59: 955-965.

559 Marohn, L., Prigge, E. \& Hanel, R. 2014. Escapement success of silver eels from a German 560 river system is low compared to management - based estimates. Freshwater Biology 59: 6456172. 
McCauley, D.J., Pinsky, M.L., Palumbi, S.R., Estes, J.A., Joyce, F.H. \& Warner, R.R. 2015. Marine defaunation: Animal loss in the global ocean. Science 347: 1255641.

McDonald, J.H. 2009. Handbook of biological statistics: Sparky House Publishing Baltimore, MD.

Montgomery, J., Carton, G., Voigt, R., Baker, C. \& Diebel, C. 2000. Sensory Processing of Water Currents by Fishes. Philosophical Transactions: Biological Sciences 355: 1325-1327. Montgomery, J., Coombs, S. \& Halstead, M. 1995. Biology of the mechanosensory lateral line in fishes. Reviews in Fish Biology and Fisheries 5: 399-416.

Nestler, J.M., Goodwin, A.R. \& Chapman, S.R. 2000. Development of a Numerical Fish Surrogate for Improved Selection of Fish Passage Design and Operation Alternatives for Lower Granite Dam; Phase 1. U.S. Army Corps of Engineers, Engineer Research and Development Center.

Newbold, L., Hockley, F., Williams, C., Cable, J., Reading, A., Auchterlonie, N. \& Kemp, P. 2015. Relationship between European eel Anguilla anguilla infection with non - native parasites and swimming behaviour on encountering accelerating flow. Journal of Fish Biology 86: 1519-1533.

Odeh, M. \& Orvis, C. 1998. Downstream fish passage design considerations and developments at hydroelectric projects in the North-east USA. Fish Migration and Fish Bypasses: 267.

Palstra, A.P., Heppener, D.F.M., van Ginneken, V.J.T., Szekely, C. \& van den Thillart, G.E.E.J.M. 2007. Swimming performance of silver eels is severely impaired by the swimbladder parasite Anguillicola crassus. Journal of Experimental Marine Biology and Ecology 352: $244-256$.

Pankhurst, N.W. 1982. Relation of visual changes to the onset of sexual maturation in the European eel Anguilla anguilla L. Journal of Fish Biology 21: 127-140. 
587 Peake, S. \& McKinley, R. 1998. A re-evaluation of swimming performance in juvenile 588 salmonids relative to downstream migration. Canadian Journal of Fisheries and Aquatic Sciences 55: 682-687.

Piper, A.T., Wright, R.M., Walker, A.M. \& Kemp, P.S. 2013. Escapement, route choice, barrier passage and entrainment of seaward migrating European eel, Anguilla anguilla, within a highly regulated lowland river. Ecological Engineering 57: 88-96. of seaward-migrating European eel (Anguilla anguilla) to manipulated flow fields. 364: $147-155$.

Ruggles, C. 1980. A review of the downstream migration of Atlantic salmon. Canadian Technical Report of Fisheries and Aquatic Sciences 952.

600 Russon, I.J. \& Kemp, P.S. 2011. Advancing provision of multi-species fish passage: Behaviour of adult European eel (Anguilla anguilla) and brown trout (Salmo trutta) in response to accelerating flow. Ecological Engineering 37: 2018-2024. Freshwater Fish 19: 197-205.

Schilt, C.R. 2007. Developing fish passage and protection at hydropower dams. Applied Animal Behaviour Science 104: 295-325. optimization of fish guidance efficiency (FGE) at a behavioural fish protection system for downstream migrating Atlantic salmon (Salmo salar) smolts. River research and applications 19: 605-617. 
612 Scruton, D., Pennell, C., Bourgeois, C., Goosney, R., King, L., Booth, R., Eddy, W., Porter, 613 T., Ollerhead, L.M.N. \& Clarke, K. 2008. Hydroelectricity and fish: a synopsis of 614 comprehensive studies of upstream and downstream passage of anadromous wild Atlantic 615 salmon, Salmo salar, on the Exploits River, Canada. Hydrobiologia 609: 225-239. 616 Silva, A.T., Katopodis, C., Tachie, M.F., Santos, J.M. \& Ferreira, M.T. (in press). 617 Downstream Swimming Behaviour of Catadromous and Potamodromous Fish Over Spillways. River Research and Applications.

619 Simpson, M.R. 2001. Discharge measurements using a broad-band acoustic Doppler current 620 profiler: US Department of the Interior, US Geological Survey.

Smith, D.L., Goodwin, R.A. \& Nestler, J.M. 2014. Relating Turbulence and Fish Habitat: A New Approach for Management and Research. Reviews in Fisheries Science \& Aquaculture 22: $123-130$.

624 Smith, L.S. 1982. Decreased swimming performance as a necessary component of the smolt migration in salmon in the Columbia River. Aquaculture 28: 153-161. Solomon, D. \& Beach, M. 2004. Fish Pass Design For Eel and Elver (Anguilla anguilla). Environment Agency, Bristol SonTek. 2010. RiverSurveyor S5/M9 System Manual. Firmware Version 1.0. San Diego: SonTek, YSI.

630 Svendsen, J.C., Aarestrup, K., Deacon, M.G. \& Christensen, R.H. 2010. Effects of a surface oriented travelling screen and water abstraction practices on downstream migrating Salmonidae smolts in a lowland stream. River Research and Applications 26: 353-361. Svendsen, J.C., Aarestrup, K., Malte, H., Thygesen, U.H., Baktoft, H., Koed, A., Deacon, M.G., Fiona Cubitt, K. \& Scott McKinley, R. 2011. Linking individual behaviour and migration success in Salmo salar smolts approaching a water withdrawal site: implications for management. Aquatic Living Resources 24: 201-209. 
637

638

639

640

641

642

643

644

645

646

647

648

649

650

651

652

653

654

655

656

657

658

659

660

Svendsen, J.C., Eskesen, A.O., Aarestrup, K., Koed, A. \& Jordan, A.D. 2007. Evidence for non-random spatial positioning of migrating smolts (Salmonidae) in a small lowland stream. Freshwater Biology 52: 1147-1158.

Tesch, F.W. 2003. The Eel. Biology and management of anguillid eels. Oxford: Blackwell Science Ltd. 408 pp.

Thorpe, J. \& Morgan, R. 1978. Periodicity in Atlantic salmon Salmo salar L. smolt migration. Journal of Fish Biology 12: 541-548.

Toniolo, H. 2014. The Effects of Surface Debris Diversion Devices on River Hydrodynamic Conditions and Implications for In-Stream Hydrokinetic Development. Water 6: 2164-2174. Travade, F., Larinier, M., Subra, S., Gomes, P. \& De-Oliveira, E. 2010. Behaviour and passage of European silver eels (Anguilla anguilla) at a small hydropower plant during their downstream migration. Knowledge and Management of Aquatic Ecosystems 398: 1- 19.

Turnpenny, A.W.H., Struthers, G. \& Hanson, K.P. 1998. A UK guide to intake fish-screening regulations, policy and best practice. Contractors report to the Energy Technology Support Unit, Harwell. ETSU H/00052/00/00.

Tytler, P., Thorpe, J. \& Shearer, W. 1978. Ultrasonic tracking of the movements of Atlantic salmon smolts (Salmo salar L) in the estuaries of two Scottish rivers. Journal of Fish Biology 12: $575-586$.

van Beurden, S.J., Engelsma, M.Y., Roozenburg, I., Voorbergen-Laarman, M.A., van Tulden, P.W., Kerkhoff, S., van Nieuwstadt, A.P., Davidse, A. \& Haenen, O. 2012. Viral diseases of wild and farmed European eel Anguilla anguilla with particular reference to the Netherlands. Diseases of Aquatic Organanisms 101: 69-86.

Van Ginneken, V., Ballieux, B., Willemze, R., Coldenhoff, K., Lentjes, E., Antonissen, E., Haenen, O. \& van den Thillart, G. 2005. Hematology patterns of migrating European eels and 
661 the role of EVEX virus. Comparative Biochemistry and Physiology Part C: Toxicology \& 662 Pharmacology 140: 97-102.

663 Verbiest, H., Breukelaar, A., Ovidio, M., Philippart, J.C. \& Belpaire, C. 2012. Escapement 664 success and patterns of downstream migration of female silver eel Anguilla anguilla in the 665 River Meuse. Ecology of Freshwater Fish 21: 395-403.

666 White, E. \&. Knights, B. 1997. Dynamics of upstream migration of the European eel, 667 Anguilla anguilla (L.), in the Rivers Severn and Avon, England, with special reference to the 668 effects of man made barriers. Fisheries Management and Ecology 4: 311-324.

669 Williams, J. G., Armstrong, G., Katopodis, C., Larinier, M., \& Travade, F. 2012. Thinking 670 like a fish: A key ingredient for development of effective fish passage facilities at river 671 obstructions. River Research and Applications 28: 407-417.

672 Winter, H.V., Jansen, H.M. \& Bruijs, M.C.M. 2006. Assessing the impact of hydropower and 673 fisheries on downstream migrating silver eel, Anguilla anguilla, by telemetry in the River 674 Meuse. Ecology of Freshwater Fish 15: 221-228. 
